\title{
Effect of environmentally sustainable microbial fertilizer on Insect-induced plant responses
}

\author{
Rubabura J. A. K., ${ }^{1}$ Sharma G. ${ }^{2}$ and Mathur V. ${ }^{2}$ 瓜
}

Received: 20.03.2019

Revised: 28.05.2019

Accepted: 10.06.2019

\begin{abstract}
Application of Vesicular Arbuscular Mycorrhiza (VAM) is well known as an environmentally sustainable alternative to chemical fertilizers. However, its efficacy in fortifying plants against damage is still not known. We studied the effect of damage mechanically or by generalist caterpillar, Tobacco cutworm (Spodoptera litura), on soybean (Glycine max) was grown in soil containing VAM. Changes in chlorophyll, carotenoids, phenol and tannin were compared. We found that VAM not only facilitated improvement in growth parameters of soybean, but aided the increase in primary and secondary metabolites following damage. Thus, VAM may prove to be a promising environmentally-sustainable fertilizer in fields.
\end{abstract}

Key words: Chlorophyll a and b, Carotenoids, Phenols, Spodoptera litura, Tannins, Vesicular arbuscular mycorrhiza

\section{Introduction}

Microbial fertilizers are emerging as efficient growth promoters in sustainable agriculture systems. These beneficial soil microorganisms play an essential role in decomposing the organic matter of the soil and there by release macro as well as micro nutrients necessary for plant growth (Van der Heijden et al., 2008). Commonly used chemical fertilizers not only have a high processing cost but their excessive use can cause aggregation of soil nutrients. Moreover, there is a soil run-off pollution risk (Aktar et al., 2009). Microbial fertilizers on the other hand are cost effective as well as help in releasing bound nutrients from the soil. Vesicular arbuscular mycorrhiza (VAM) is a fungal biofertilizer which acts as an obligate symbiont to many crops (Tylka et al., 1991). VAM increases the soil nitrogen and phosphorus uptake in the host plant which influences their growth in exchange for its carbon requirements (Soka and Ritchie, 2014). It penetrates into the roots of the host and triggers a series of biochemical and

\section{Author's Address}

${ }^{1}$ Agricultural Entomology lab, Department of Biology, Research Centre in Natural Sciences, CRSN/Lwiro, DS/Bukavu, DRC Congo

${ }^{2}$ Animal Plant Interactions lab, Department of Zoology, Sri Venkateswara College, University of Delhi, Benito Juarez Marg, Dhaula Kuan, New Delhi-110021, India

E-mail.:vmathur@svc.ac.in cytological events. These events are initiated by penetration of elicitor molecule in the host cell which further lead to series interdependent reactions such as activation of defense genes alteration of membrane permeability, activation of enzymes bound to plasma membrane and generation of small signaling molecules (Song et al., 2011). These changes are vital for VAM establishment in host. However, penetration of a foreign microbe can induce production of metabolites in the plants that help the plant in defending against the microbe effects. Plant secondary metabolites are highly diverse in their structure and chemical nature. These metabolites, unlike traditional primary metabolites (carbohydrates, proteins, lipids, nucleic acids), do not directly play a role in the vital physiological functions of the plants. They are however, important for plant defence mechanisms (Jeaun et al., 2005; Nicholson and Hammerschmidt, 1992; Maillard, 1996). Secondary metabolites are present in all higher plants and have a mutually exclusive distribution within the plant family (Wink, 2003). Phenolic compounds or polyphenols are a family of molecules widespread in the plant kingdom. This class of compounds includes phenolic acids (simple phenols), flavonoids, lignins, stilbenes, coumarins and tannins (Glombitza and Gerstberger, 1985; 


\section{Rubabura et al.}

Harborne, 1980; Boros et al., 2010). They are important for the defense mechanism in plants against pathogenic microbes as well as insect herbivores. These compounds elevate the activity of oxidative enzymes when the host cell is invaded (War et al., 2012). Tannins also play an important role in plant defense against pathogens such as bacterial, fungal and nematode attack by accumulating on the area of invasion and thereby inhibiting their further development (Feucht et al., 1997; Collingborn et al., 2000). They are also reported to help against attack by insects and other herbivores, as the presence of tannins makes the plant less palatable for them (Mueller-Harvey and Mc Allan, 1992; Woodward and Coppock, 1995; Feucht et al., 1997; Jean-Blain, 1998; Bennick, 2002).

Soybean (Glycine $\max$ [L.]) is a widely used leguminous crop belonging to Leguminosae (Fabaceae) contributing to $68 \%$ of the legumes worldwide (Naamala et al., 2016). It is a rich protein and oil source and used as both foods as well as feed crop in livestock industry (MateosAparicio et al., 2008; Dei, 2011; Mapope and Dakora, 2016). However due to high protein content in its seeds, soybean requires a large amount of $\mathrm{N}$ and $\mathrm{P}$ (Fujikake et al., 2003; Riaz, 2006). In order to obtain the optimum yield of soybean, it is important to use both nitrogen fixation in the nodules and inorganic nitrogen assimilation in the roots. Moreover, unavailability of free phosphorus causes further constraint in soybean cultivation. Thus, addition of VAM not only provides $\mathrm{N}$ fixation for the plants but also works as P- solubilizing bio-fertilizer, thereby improving $\mathrm{N}$ and $\mathrm{P}$ uptake in the plant. Studies have also shown VAM to help plant growth under drought and salinity stress (Aliasgharzad et al., 2006; He et al., 2007). However, whether VAM supplementation can also help the plant immunity against insect attack or whether biofertilizerfacilitated development results in immunity tradeoff, is still unclear. Therefore, we studied the effect of the microbial fertilizer VAM on induced responses against the generalist insect Spodoptera litura in soybean in terms of plant growth, primary and secondary metabolites. We further studied the variation in metabolite response against mechanical and insect injury in VAM supplemented soybean plants.

\section{Material and methods}

Plants: Soybean (Glycine max) variety Pusa-9712 seeds were obtained from Indian Agricultural Research Institute (IARI), New Delhi. Plants were grown in earthen pots of 6-inch diameter in an insect free plant enclosure at Sri Venkateswara college, New Delhi. Seeds were sown in supplementation with VAM in the ratio $10 \mathrm{gm}$ per $\mathrm{kg}$ of soil. Control plants were sown without any microbial bio-fertilizer supplementation. All the plants were measured for relative leaf count and shoot length after every two weeks.

VAM attachment to plants: VAM root attachments were observed in the plant during the first week of plant sowing. From the day the cotelydon growth was observed, three plants were removed from soil and the roots were washed with double distilled water to remove dust particles. These roots were then stained with lactophenol cotton blue stain for $5 \mathrm{~min}$ and observed under the microscope in order to verify VAM attachment.

Insects: Spodoptera litura were reared on castor leaves in $10 \mathrm{~cm}$ dia x $15 \mathrm{~cm}$ containers at AnimalPlant interactions lab, Sri Venkateswara College. The larvae were maintained at $28 \pm 2{ }^{\circ} \mathrm{C}$ and $60-70$ $\% \mathrm{RH}$. The adult moths were given $10 \%$ honey solution fortified with multi vitamins.

Induction: The induction of the plants was performed when the plants reached stage 12 on the BBCH scale (Lancashire et al., 1991). Overnight water satiated third instar $S$. litura were released on the $4^{\text {th }}$ leaf of the plant in $4 \mathrm{~cm}$ dia $\times 2 \mathrm{~cm}$ plastic clip cages in 15 replicates on both VAM supplemented as well as un-supplemented control plants. The insects were left to feed on the plants for $24 \mathrm{~h}$. Equal numbers of plants were injured on the $4^{\text {th }}$ leaf with a punching machine on the fourth leaf for mechanically damaging the plants (Mithöfer et al., 2005). The same number of undamaged plants from both VAM supplementation and plants grown in soil without VAM, received empty clip cages. The experiments were divided into short duration effects $(24 \mathrm{~h})$ and long duration effects ( 3 and 7 day). The test sets used were as follows: VAM supplemented plants without damage (VUN), VAM supplemented plants with mechanical damage (VM), VAM supplemented plants with insect damage (VI), control plants without damage (CUN), control 
plants with mechanical damage $(\mathrm{CM})$ and control plants with insect damage (CI).

Phenols and Tannin estimation: Phenol and tannin estimation was done at day 20 and day 34. Ten replicates were tested from each treatment. About $100 \pm 0.03 \mathrm{mg}$ samples of leaf were finely grounded in 10 times the volume of $80 \%$ ethanol. Samples were then centrifuged at $10,000 \mathrm{x}$ g at 4 ${ }^{\circ} \mathrm{C}$ for 20 minutes. Supernatant was collected in a tube and evaporated at $50{ }^{\circ} \mathrm{C}$ overnight. The residue was re-dissolved in $5 \mathrm{ml}$ of water. The sample thus obtained was divided into two parts. Using 1N Folin - Ciocalteu reagent method, first part was used for phenol estimation and the second part was used for tannin estimation (Makkar et al., 2007). Different concentrations from $10-100 \mu \mathrm{g}$ of Tannic acid was used as standard for the relative content estimation.

Chlorophyll and carotenoid estimation: Chlorophyll and carotenoid estimation was done at day 20 and day 34 in a set of ten replicates from each treatment set. About $0.1 \mathrm{gm}$ of leaf was grounded till liquification in $10 \mathrm{~mL}$ of $80 \%$ acetone in dark (Arnon, 1949). The grounded sample was filtered with filter paper and absorbance was measured at 663, 645 and $470 \mathrm{~nm}$. The calculations were done according to the following equations:

$$
\text { Chl a }\left(\frac{m g}{g}\right)=\frac{\left[\left(12.7 x A_{663}\right)-\left(2.6 x A_{645}\right)\right]}{m g \text { leaf tissue }} x \mathrm{ml} \text { of acetone }
$$

Chl b $\left(\frac{m g}{g}\right)=\frac{\left[\left(22.9 x A_{645}\right)-\left(4.68 x A_{663}\right)\right]}{m g \text { leaf tissue }} x$ ml of acetone

$\operatorname{Car}_{(\text {Carotene\&xanthophyll })}=\frac{1000 A_{470}-1.9 x \text { Chla }-63.14 x \text { Chlb }}{214}$

Estimation of plant biomass: After removing the leaf samples, plants were collected individually in separate paper envelopes and were then heated at $100{ }^{\circ} \mathrm{C}$ for $48 \mathrm{~h}$. The plants were again measured for their dry weight content and measured on weighing balance (Mettler Toledo, India).

Statistics: One-way ANOVA with StudentNewman-Keuls posthoc test was done using the SigmaPlot software (ver 12.0).

\section{Results and Discussion}

The root started growing approximately on the 5th day of sowing and VAM attachment was observed as early as $2^{\text {nd }}$ day of root development which was observed about 7 days after sowing (figure 1). A significant height increase was observed in inoculated soybean seedlings after 20 and 34 days after sowing (figure 2). Height growth of inoculated soyabean of 20 and 34 days was highly significant as compared to the non-inoculated plants. There was no significant difference in the number of leaves between inoculated and non-inoculated plants at day 20 of sowing. However, the number of leaves present in supplemented soybean at the end of 34 days was highly significant as compared to the non-supplemented plants $(F=183.134, P<0.001)$ (figure 3). Dry matter of soybean growth of supplemented plant of 34 days was highly significant as compared to the non-supplemented plants. Thus, soybean plants with VAM interaction have significantly high dry matter than plants without VAM on the two days after sowing (figure 4). Both treatment $(\mathrm{F}=81, \mathrm{P}<0.001)$ and day $(\mathrm{F}=3.003, \mathrm{P}<0.001)$ had a significant effect on the phenol concentration. Phenol content significantly increased in 34 day old plants supplemented with VAM after $24 \mathrm{~h}$ of damage, which remained elevated aeven after 3 days of damage, specifically in VI set. A slight increase in phenols with mechanical and insect damage (CM and $\mathrm{CI}$ ) was also observed in control set of plants on day 3 of damage in the same age set (34 day old). No significant change in phenols of 20day old plants irrespective of treatment, was observed at $24 \mathrm{~h}$ of damage $(\mathrm{P}<0.001)$. However, after 3 days of damage in 20 day old plants, a decrease in phenols was observed in VAM supplemented plants, especially in VUN and VI sets. In 20 day plants, tannin content decreased after $24 \mathrm{~h}$ of insect damage $(\mathrm{P}<0.001)$, whereas in 34 day old plants, tannin content was significantly increased with both VAM supplementation as well as damage $(\mathrm{P}<0.001)$ (Table 2). Similar to phenols, tannin content also decreased in 20 day old plants compared with CUN after 3 days of damage irrespective of VAM supplementation $(\mathrm{P}<0.001)$. On the contrary in 34 day old plants tannins significantly increased after 3 days of damage irrespective of VAM supplementation $\quad(\mathrm{P}<0.001)$. 


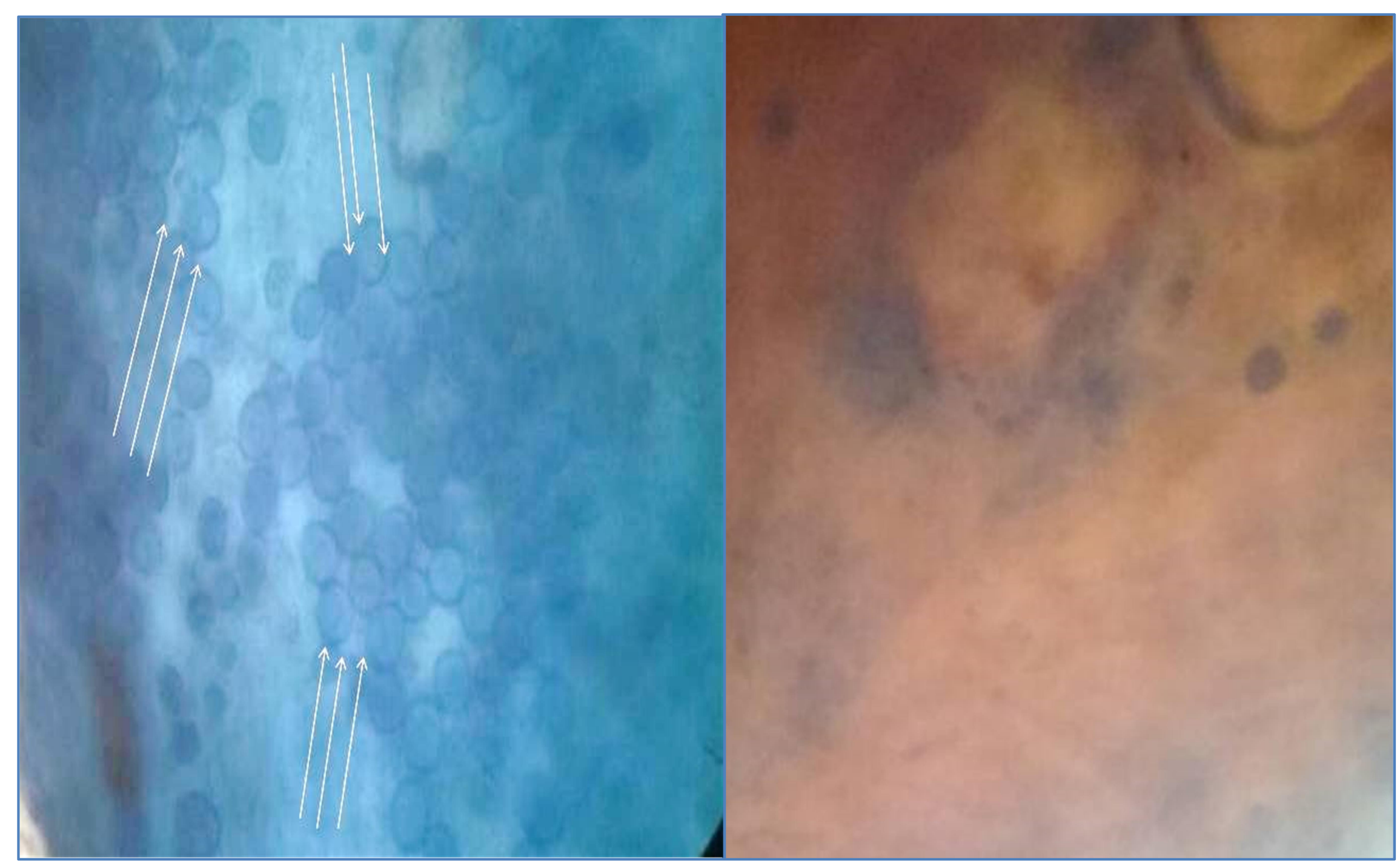

Figure 1: (a) VAM attachment inside the root tissues of VAM supplemented plants stained with fungi specific stain lactophenol cotton blue and (b) Unstained roots of plants without VAM supplementation (control) 
Effect of environmentally sustainable microbial fertilizer

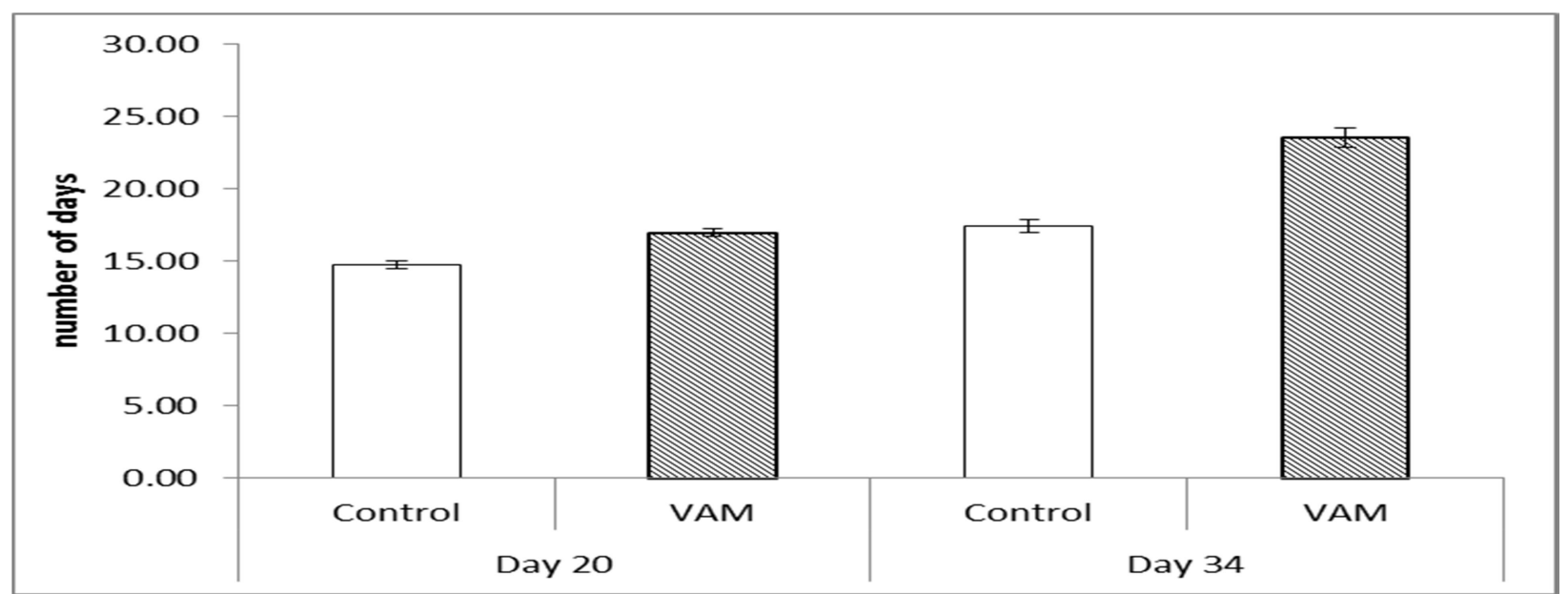

Figure 2: Mean ( \pm S.E.) height of control and VAM supplemented soybean plants on day 20 and day 34 after sowing

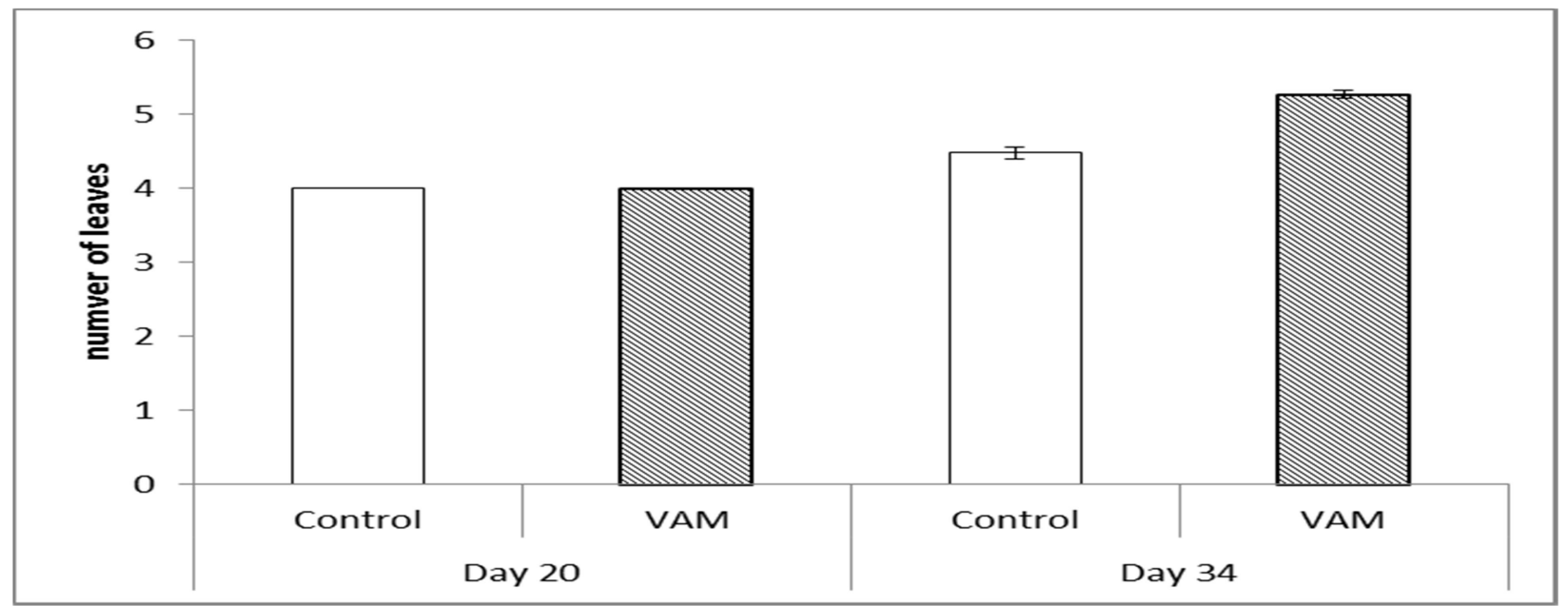

Figure 3: Mean ( \pm S.E.) number of leaves in control and VAM supplemented soybean plants on day 20 and day 34 after sowing

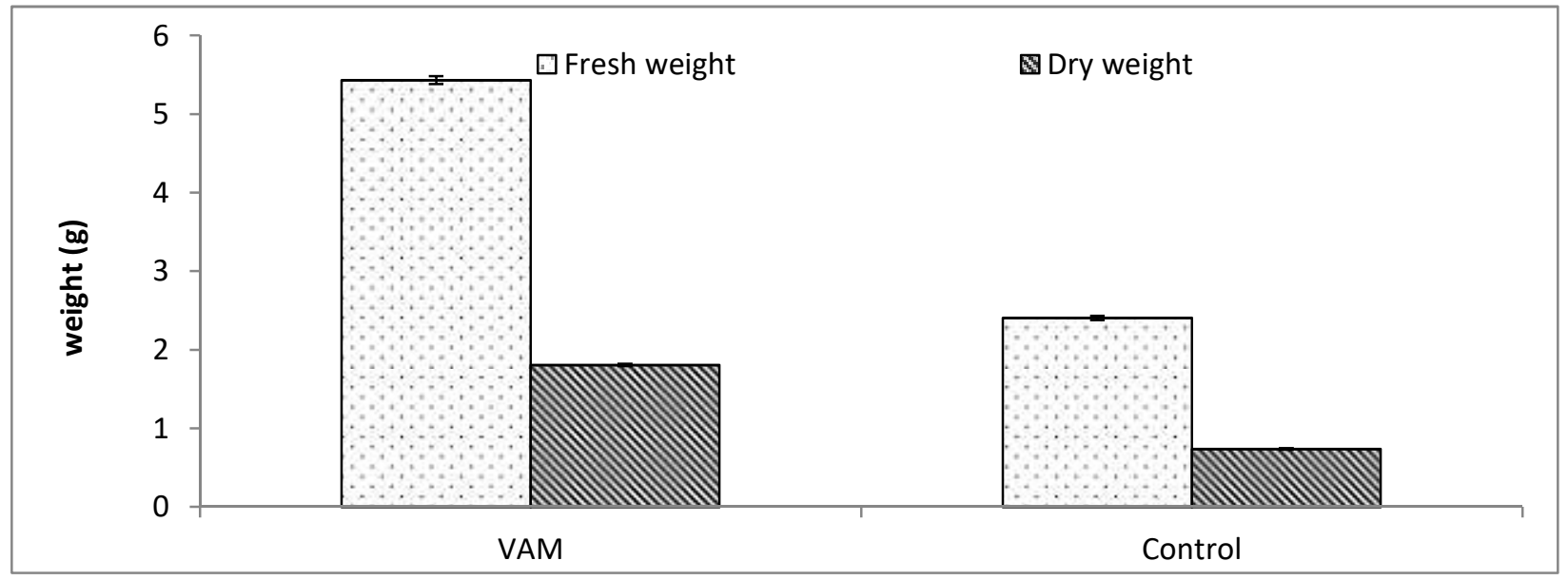

Figure 4: Mean ( \pm S.E.) dry matter of control and VAM supplemented soybean plants on day 34 after sowing 
Rubabura et al.

Table 1: Concentration of phenols (day 1 and 3) ( $\mu \mathrm{g} / \mathrm{g}$ of leaf weight) using one way analysis of variance

\begin{tabular}{|c|c|c|c|c|}
\hline \multirow{2}{*}{} & \multicolumn{2}{|c|}{ Day 1 } & \multicolumn{2}{c|}{ Day 3 } \\
\cline { 2 - 5 } & \multicolumn{2}{|c|}{ Means \pm Standard error } & \multicolumn{2}{c|}{ Means \pm Standard error } \\
\cline { 2 - 5 } & 20 day & 34 day & 20 day & 34 day \\
\hline VUN & $6.95 \mathrm{a} \pm 2.18$ & $9.13^{\mathrm{b}} \pm 1.78$ & $1.58 \mathrm{a} \pm 1.05$ & $1.90^{\mathrm{ab}} \pm 1.17$ \\
\hline VM & $3.27^{\mathrm{a}} \pm 1.52$ & $9.90^{\mathrm{b}} \pm 1.40$ & $4.24^{\mathrm{b}} \pm 1.30$ & $2.15^{\mathrm{b}} \pm 0.88$ \\
\hline VI & $4.87^{\mathrm{a}} \pm 2.11$ & $8.01^{\mathrm{b}} \pm 1.27$ & $1.43^{\mathrm{a}} \pm 0.90$ & $4.19^{\mathrm{c}} \pm 0.14$ \\
\hline CUN & $5.62^{\mathrm{a}} \pm 1.94$ & $2.82^{\mathrm{a}} \pm 1.85$ & $8.20^{\mathrm{c}} \pm 0.87$ & $0.49^{\mathrm{a}} \pm 0.49$ \\
\hline CM & $5.99^{\mathrm{a}} \pm 2.15$ & $8.10^{\mathrm{b}} \pm 1.91$ & $5.16^{\mathrm{c}} \pm 1.03$ & $1.73^{\mathrm{ab}} \pm 1.06$ \\
\hline CI & $2.19^{\mathrm{a}} \pm 1.18$ & $4.64^{\mathrm{ab}} \pm 2.00$ & $0.74^{\mathrm{a}} \pm 0.69$ & $1.18^{\mathrm{ab}} \pm 0.53$ \\
\hline P & $<0.001$ & $<0.001$ & $<0.001$ & $<0.001$ \\
\hline Significance & $* *$ & $* *$ & $* *$ & $* *$ \\
\hline
\end{tabular}

$* *$ : Significant and NS: Non-Significant.

Table 2: Concentration of tannins (day 1 and 3) ( $\mu \mathrm{g} / \mathrm{g}$ of leaf weight) using one way ANOVA

\begin{tabular}{|c|c|c|c|c|}
\hline \multirow{2}{*}{} & \multicolumn{2}{|c|}{ Day 1 } & \multicolumn{2}{c|}{ Day 3 } \\
\cline { 2 - 5 } & \multicolumn{2}{|c|}{ Means \pm Standard error } & 20 day & 34 day \\
\cline { 2 - 5 } & 20 day & 34 day & $9.54^{\mathrm{a}} \pm 6.33$ & $1.89^{\mathrm{b}} \pm 1.20$ \\
\hline VUN & $3.68^{\mathrm{b}} \pm 1.03$ & $4.37^{\mathrm{c}} \pm 0.70$ & $25.43^{\mathrm{b}} \pm 8.19$ & $3.22^{\mathrm{b}} \pm 2.16$ \\
\hline VM & $3.67^{\mathrm{b}} \pm 0.77$ & $3.27^{\mathrm{b}} \pm 0.31$ & $10.45^{\mathrm{a}} \pm 6.91$ & $3.55^{\mathrm{b}} \pm 0.49$ \\
\hline VI & $2.71^{\mathrm{ab}} \pm 0.98$ & $4.53^{\mathrm{c}} \pm 0.94$ & $49.02^{\mathrm{b}} \pm 4.42$ & $0.01^{\mathrm{a}} \pm 0.01$ \\
\hline CUN & $3.79^{\mathrm{b}} \pm 1.41$ & $0.89^{\mathrm{a}} \pm 0.58$ & $37.86^{\mathrm{b}} \pm 7.36$ & $0.84^{\mathrm{b}} \pm 0.52$ \\
\hline CM & $4.64^{\mathrm{b}} \pm 1.13$ & $4.67^{\mathrm{c}} \pm 1.25$ & $5.56^{\mathrm{a}} \pm 5.56$ & $2.33^{\mathrm{b}} \pm 1.26$ \\
\hline CI & $1.32^{\mathrm{a}} \pm 0.46$ & $2.20^{\mathrm{a}} \pm 0.87$ & $<0.001$ & $<0.001$ \\
\hline P & $<0.001$ & $<0.001$ & $* *$ & $* *$ \\
\hline Significance & $* *$ & $* *$ & & \\
\hline
\end{tabular}

**: Significant and NS: Non-Significant.

Table 3. Concentration of chlorophyll a ( $\mu \mathrm{g} / \mathrm{g}$ of leaf weight) at day 3 and 7

\begin{tabular}{|c|c|c|c|c|}
\hline \multirow{2}{*}{} & \multicolumn{2}{|c|}{ Day 3 } & \multicolumn{2}{c|}{ Day 7 } \\
\cline { 2 - 5 } & \multicolumn{2}{|c|}{ Means \pm Standard error } & 20 day & 34 day \\
\cline { 2 - 5 } & 20 day & 34 day & $0.83^{\mathrm{c}} \pm 0.23$ & $0.41^{\mathrm{a}} \pm 0.19$ \\
\hline VUN & $1.34^{\mathrm{b}} \pm 0.34$ & $0.24^{\mathrm{a}} \pm 0.07$ & $1.15^{\mathrm{c}} \pm 0.22$ & $0.46^{\mathrm{a}} \pm 0.28$ \\
\hline VM & $0.13^{\mathrm{a}} \pm 0.13$ & $0.22^{\mathrm{a}} \pm 0.14$ & $0.35^{\mathrm{b}} \pm 0.24$ & $0.46^{\mathrm{a}} \pm 0.22$ \\
\hline VI & $0.36^{\mathrm{ab}} \pm 0.36$ & $0.43^{\mathrm{a}} \pm 0.14$ & $0.12^{\mathrm{b}} \pm 0.09$ & $0.57^{\mathrm{a}} \pm 0.15$ \\
\hline CUN & $0.78^{\mathrm{b}} \pm 0.28$ & $0.24^{\mathrm{a}} \pm 0.04$ & $0.38^{\mathrm{b}} \pm 0.18$ & $0.75^{\mathrm{a}} \pm 0.10$ \\
\hline CM & $1.10^{\mathrm{b}} \pm 0.30$ & $0.29^{\mathrm{a}} \pm 0.13$ & $0.05^{\mathrm{a}} \pm 0.03$ & $0.25^{\mathrm{a}} \pm 0.15$ \\
\hline CI & $1.18^{\mathrm{b}} \pm 0.25$ & $0.22^{\mathrm{a}} \pm 0.09$ & $<0.001$ & 0.011 \\
\hline P & $<0.001$ & 0.043 & $* *$ & $* *$ \\
\hline Significance & $* *$ & $* *$ & ${ }^{*}$ &
\end{tabular}

**: Significant and NS: Non-Significant 
Effect of environmentally sustainable microbial fertilizer

Table 4. Concentration of chlorophyll $b(\mu \mathrm{g} / \mathrm{g}$ of leaf weight) at day 3 and 7

\begin{tabular}{|c|c|c|c|c|}
\hline \multirow{2}{*}{} & \multicolumn{2}{|c|}{ day 3 } & \multicolumn{2}{c|}{ day 7 } \\
\cline { 2 - 5 } & \multicolumn{2}{|c|}{ Means \pm Standard error } & 20 day & 34 day \\
\cline { 2 - 5 } & 20 day & 34 day & $0.45^{\mathrm{c}} \pm 0.11$ & $0.22^{\mathrm{b}} \pm 0.08$ \\
\hline VUN & $0.67^{\mathrm{c}} \pm 0.12$ & $0.24^{\mathrm{a}} \pm 0.06$ & $0.16^{\mathrm{a}} \pm 0.08$ & $0.232^{\mathrm{bc}} \pm 0.13$ \\
\hline VM & $0.17^{\mathrm{a}} \pm 0.05$ & $0.43^{\mathrm{a}} \pm 0.12$ & $0.61^{\mathrm{c}} \pm 0.10$ & $0.045^{\mathrm{a}} \pm 0.09$ \\
\hline VI & $0.07^{\mathrm{a}} \pm 0.13$ & $0.22^{\mathrm{a}} \pm 0.12$ & $0.12^{\mathrm{a}} \pm 0.07$ & $0.295^{\mathrm{bc}} \pm 0.05$ \\
\hline CUN & $0.41^{\mathrm{b}} \pm 0.12$ & $0.21^{\mathrm{a}} \pm 0.03$ & $0.09^{\mathrm{ab}} \pm 0.09$ & $0.129^{\mathrm{ab}} \pm 0.04$ \\
\hline CM & $0.68^{\mathrm{c}} \pm 0.14$ & $0.22^{\mathrm{a}} \pm 0.11$ & $0.23^{\mathrm{b}} \pm 0.05$ & $0.382^{\mathrm{c}} \pm 0.07$ \\
\hline CI & $0.55^{\mathrm{b}} \pm 0.17$ & $0.29^{\mathrm{a}} \pm 0.08$ & $<0.001$ & $<0.001$ \\
\hline P & $<0.001$ & $<0.001$ & $* *$ & $* *$ \\
\hline Signification & $* *$ & $* *$ & & $* * 1$ \\
\hline
\end{tabular}

**: Significant and NS: Non-Significant.

Table 5. Concentration of carotenoid (xanthophyll \& carotene) ( $\mu \mathrm{g} / \mathrm{g}$ of leaf weight) at day 3 and 7

\begin{tabular}{|c|c|c|c|c|}
\hline \multirow{2}{*}{} & \multicolumn{2}{|c|}{$\begin{array}{c}\text { Carotenoid ( Xanthophyll \& carotene) } \\
\text { day 3 }\end{array}$} & $\begin{array}{c}\text { Carotenoid ( Xanthophyll \& carotene) } \\
\text { day } 7\end{array}$ \\
\cline { 2 - 5 } & \multicolumn{2}{|c|}{ Means \pm Standard error } & \multicolumn{2}{c|}{ Means \pm Standard error } \\
\cline { 2 - 5 } & 20 day & 34 day & 20 day & 34 day \\
\hline VUN & $1545.86^{\mathrm{b}} \pm 200.11$ & $429.42^{\mathrm{b}} \pm 118.56$ & $1628.29^{\mathrm{b}} \pm 873.29$ & $619.35^{\mathrm{ab}} \pm 280.60$ \\
\hline VM & $232.14^{\mathrm{a}} \pm 175.48$ & $297.56^{\mathrm{a}} \pm 179.68$ & $2383.27^{\mathrm{b}} \pm 850.58$ & $268.72^{\mathrm{a}} \pm 195.67$ \\
\hline VI & $383.26^{\mathrm{ab}} \pm 289.72$ & $869.22^{\mathrm{c}} \pm 232.48$ & $644.30^{\mathrm{ab}} \pm 880.491$ & $513.85^{\mathrm{ab}} \pm 184.47$ \\
\hline CUN & $894.80^{\mathrm{b}} \pm 226.88$ & $443.70^{\mathrm{b}} \pm 93.16$ & $430.62^{\mathrm{ab}} \pm 747.43$ & $703.83^{\mathrm{b}} \pm 106.42$ \\
\hline CM & $1130.75^{\mathrm{b}} \pm 229.77$ & $404.35^{\mathrm{b}} \pm 142.90$ & $902.15^{\mathrm{ab}} \pm 825.47$ & $877.46^{\mathrm{bc}} \pm 65.49$ \\
\hline CI & $1467.769^{\mathrm{b}} \pm 220.39$ & $427.26^{\mathrm{b}} \pm 158.77$ & $70.63^{\mathrm{a}} \pm 95.57$ & $287.49^{\mathrm{a}} \pm 149.56$ \\
\hline P & $<0.001$ & $<0.001$ & $<0.001$ & $<0.001$ \\
\hline Signification & $* *$ & $* *$ & $* *$ & $* *$ \\
\hline
\end{tabular}

**: Significant and NS: Non-Significant.

In 20 day old plants, VM showed a significant after 3 days and 7 days of damage. Chlorophyll $b$ decrease, in chlorophyll $a$ content after 3 days of content, in 20 day VAM plants (VM and VI) was damage whereas after 7 days of damage, significantly decreased after 3 days of damage chlorophyll $a$ significantly decreased in insect $(\mathrm{P}<0.001)$. Chlorophyll $b$ in this set of VM plants damaged plants (both VI and CI) $(\mathrm{P}<0.001)$ (Table remained low even after 7 days of damage, whereas $3)$. On the contrary, in 34 day old plants, no it significantly increased in 20 day old VI plants significant change in chlorophyll $a$ was observed (Table 4). In contrast, in 20 day old CI plants 
Chlorophyll $b$ showed increase after 3 day of damage and subsided on day 7. 34 day old plants, showed no significant change in Chlorophyll $b$ content after 3 days of damage, whereas it significantly decreased in VI on day 7 of damage. On the contrary 34 day old CI plants showed an increase in Chlorophyll $b$ content after 7 day of damage $(\mathrm{P}<0.001)$.

In 20 day old plants, significantly deacresed carotenoids was observed in VM plants on 3rd day of damage, these levels however increased after 7 days of damage $(\mathrm{P}<0.001)$ (Table 5). An overall increase was observed in VAM supplemented plants after day 7 of damage. In 34 day old plants, VM again showed decreased carotenoid $(\mathrm{P}<0.001)$. However, VI plants showed significantly increased carotenoid content, which decreased by day 7. An overall decrease in carotenoid was observed in 34 day old plants by 7 day of damage.

Symbiotic association involves most plant species and certain fungal species which has great relevance to soil ecosystem functions, especially nutrient dynamics, microbial processes, plant ecology and agriculture. VAM occur naturally and are an important component of tropical soil system. Most of the plants form symbiotic relationship with mycorrhiza, which function as a bridge for the flow of energy and matter between plants and soils (Cardon and Whitbeck, 2011). Thus VAM performs beneficial functions for crops and other microorganisms such as phosphate-solubilizing bacteria (Panhwar et al., 2009) and $\mathrm{N}_{2}$ fixing bacteria (Naher et al., 2009). In our study, VAM attachment to roots was observed as early at day 2 of root growth. VAM colonizes the host plant's roots inside the cortical tissues (Cardoso and Kuyper, 2006). The association may be either intracellular as in AMF, or extracellular as in ectomycorrhizal fungi. The root associated with the mycorrhiza have been reported to show increased active absorptive surface area and stimulate nutrient and water up take even in water stress condition (Dal Cortivo et al., 2018).

Our results indicate that VAM supplementation positively affects the height of soybean after 20 and 34 days. A previous study also reported an increase in seedlings height upon inoculation with different strains of mycorrhizal fungi (Asghari et al., 2005). During the first 20 days of sowing, there was no significant difference in number of leaves between supplemented and non-supplemented plants. This could be due to the "lag phase" effect of VAM inoculation, where a lag phase is observed between mycorrhiza inoculation and the time period when its effect is manifested in the plant (Bnindon and Shelton, 1993). The number of leaves growth of supplemented soybean at the end of 34 days was significantly increased as compared to the nonsupplemented plants. These observations are supported by higher biomass production in VAM supplemented soybean possibly due to increased phosphorus uptake. Dry matter of soybean plant supplemented with VAM was significantly elevated compared to the non-supplemented plants, indicating positive influence of VAM inoculation. Similar observations of increased biomass due to VAM inoculation due to its ability of increased nitrogen phosphorus content to plants ultimately leads to increased production of pods, seeds and grain yield in crop plants (Asghari et al., 2005; Caliskan et al., 2008).

VAM supplementation also increased phenol content in soybean as early as $24 \mathrm{~h}$ of insect damage indicating improved immune response to insect damage compared to mechanical damage in young plants (20 day old). On the other hand, 34 day old plant's immunity to mechanical damage also improved significantly upon VAM supplemention compared to control plants. However these elevated phenol levels decrease by day 3 in young plants $(20$ day old) whereas remain high in older plants (34 day old). This is possibly due to the anti-pathogenic properties of various phenolic compounds, leading to increased resistance (Nicholson and Hammerschmidt, 1992; Maillard, 1996). Phenols consist of a wide range of substances with an aromatic ring containing hydroxyl residues (OH-) and their functional derivatives which include the compounds such as catechol and protocatechuic acid, flavones, chlorogenic acid and quinones (King and Young, 1999). Together these compound form the constituent chemical barriers in plants against biotic stress (Nicholson and Hammerschmidt 1992). In contrast to phenols, tannin content did not increase significantly with damage in 20 day old VAM supplementated plants. However, it was observed to increase significantly in older plants with damage. According to Bennick (2002), soybean plant possesses sufficient amount of tannins in the natural state. The presence of tannins 
makes them less palatable plants for herbivores and thus protects the plants from excessive predation. Tannins play an important role in plant defense as they accumulate at the wound sites on the plant in case of bacteria, fungi or nematodes, and thereby inhibit their development (Woodward and Coppock, 1995; Feucht et al., 1997; Collingborn et al., 2000).

Our results showed an increased chlorophyll $a$ content in VAM supplemented plants (in both 20 and 34 day old plants) without damage (VUN) which remained higher even after day 7 of experimentation. However younger VAM supplemented soybean plants showed an increased chlorophyll $a$ content after 7 days of mechanical injury faster in comparison to plants with insect damage.

In contrast, chlorophyll $b$ content was not significantly affected by VAM supplementation and remained high in control plants. However, the control plants with damaged (CM and CI) showed increased chlorophyll $b$ content in both 20 and 34 day old plants at both the time points. A previous report suggests the increasing of chlorophyll due to a greater carbon sink belowground and the improved nutrition of the host plants facilitated by symbionts, which further lead to higher rates of photosynthesis (Aseri et al., 2008). Mycorrhiza have been reported to affect host plant by enhancing enzymatic production (Adriano-Anaya et al., 2006), increase rate of photosynthesis (Wu and Xia, 2006), enhance nitrogen fixation in host (Antunes et al., 2006) along with improving soil fertility (Charles et al., 2006). Qrbanly et al. (2006) found a positive correlation between the nitrogen and chlorophyll content of leaves, mainly due to the presence of nitrogen in the structure of chlorophyll molecules. VAM significantly increased carotenoid content in younger plant stage with no damage whereas at old stages VAM plants were able to recover from insect damage by $3^{\text {rd }}$ day which shows an improved plant response against insect herbivory. VAM supplemented plants also show an increasein the leaf carotenoid content.This is possibly doe to increased nitrogen supply facilitated by VAM inoculationwhich is also observed in parsley (Cleward et al., 2005). Moreover, nitrogen is the main constituent of all the amino acids. Correspondingly, an enhancement of protein synthesis and chloroplasts formation leads to an increase in chlorophyll and carotene (Marschner, 1995). Our study shows that soybean alone or soybean-VAM interaction can induce plant systemic resistance against predators and pathogens.

\section{Conclusion}

VAM may be considered as an environmentally sustainable alternative to chemical fertilizers and may be considered safe for use in plants, not only for improving their growth but also for their defence against insects. Further, studies may be performed in order to determine the effect of VAM on plants in an ecosystem with multiple stress at various spatial and temporal levels.

\section{Acknowledgements}

The authors would like to express their sincere gratitude to Dr. Akshay Talukdar, Sr. Scientist, I.A.R.I., New Delhi for providing Soybean Pusa 9712 seeds. The authors would also like to thank Aarti Kasba, Ankita Dhingra, Harshdeep Kaur and Tandrali Baruah, the research trainees in the Animal Plant Interactions lab at Venkateswara College, for their assistance during collection and processing of samples. We highly acknowledge the NAM S\&T centre for granting RTF-DCS fellowship- 2016 to Jean A. R. Kituta.

\section{References}

Adriano-Anaya, M. L., Salvador-Figueroa, M., Ocampo, J. A. and García-Romera, I. 2006. Hydrolytic enzyme activities in maize (Zea mays) and sorghum (Sorghum bicolor) roots inoculated with Gluconacetobacter diazotrophicus and Glomus intraradices. Soil Biology and Biochemistry, 38(5): 879-886.

Aktar, Md. W., Sengupta, D., Chowdhury, A. 2009. Impact of pesticides use in agriculture: their benefits and hazards. Interdisc Toxicol. Vol. 2(1): 1-12. doi: 10.2478/v10102009-0001-7

Aliasgharzad, N., Neyshabouri M. R., Salimi G. 2006. Effects of arbuscular mycorrhizal fungi and Bradyrhizobium japonicum on drought stress of soybean. Biologia, 61(19): S324-S328.

Antunes, P. M., De Varennes, A., Zhang, T. and Goss, M. J. 2006. The tripartite symbiosis formed by indigenous arbuscular mycorrhizal fungi, Bradyrhizobium japonicum and soya bean under field conditions. Journal of agronomy and crop science, 192(5): 373-378. 
Arnon, D. I. 1949. Copper enzyme polyphenoloxides in isolated chloroplast in Beta vulgaris. Plant Physiology, 24: $1-15$.

Aseri, G. K., Jain, N., Panwar, J., Rao, A.V. and Meghwal, P. R. 2008. Biofertilizers improve plant growth, fruit yield, nutrition, metabolism and rhizosphere enzyme activities of Pomegranate (Punica granatum L.) in Indian Thar desert. Scientia Horticulturae, 117:130-135.

Asghari, H. R., Marschner, P., Smith, S.E. and Smith, F. A. 2005. Growth response of Atriplex nummularia to mycorrhizal inoculation at different salinity levels. Plant and soil, 275:181-193.

Bennick, A. 2002. Interaction of plant polyphenols with salivary proteins. Critical Reviews in Oral Biology \& Medicine, 13 (2), 184-196.

Bnindon, N. J. and Shelton H. M. 1993. Role of vesiculararbuscular mycorrhizae in Leucacna establishment. Proceedinigs of the XVII International Grassland congress, 2064-2065.

Boros, B., Jakabová, S., Dörnyei, Á., Horváth, G., Pluhár, Z., Kilár, F. and Felinger, A. 2010. Determination of polyphenolic compounds by liquid chromatography-mass spectrometry in Thymus species. Journal of Chromatography A, 1217(51): 7972-7980.

Caliskan, S., Ozkaya, I., Caliskan, M. E. and Arsalan, M. 2008. The effect of nitrogen and iron fertilization on growth, yield and fertilizer use efficiency of soybean in Mediterranean type soil. Field Crop Resistance, 108:126123.

Cardon, Z. G. and Whitbeck, J. L. 2011. The rhizosphere: an ecological perspective. Elsevier.

Cardoso, I. M. and Kuyper, T. W. 2006. Mycorrhizas and tropical soil fertility. Agriculture, ecosystems \& environment, 116(1-2): 72-84.

Charles, P., Raj, A. D. S., Kiruba, S. 2006. Arbuscular mycorrhizal fungi in the reclamation and restoration of soil fertility. Mycorrhiza News, 18:13-14.

Chenard, C. H., Kopsell, D. A. and Kopsell, D. E. 2005. Nitrogen concentration affects nutrient and carotenoid accumulation in parsley. Journal of plant nutrition, 28(2): 285-297.

Chisholm, S. T., Coaker, G., Day, B. and Staskawicz, B. J. 2006. Host-microbe interactions: shaping the evolution of the plant immune response. Cell, 124(4): 803-814.

Collingborn, F. M., Gowen, S. R. and Mueller-Harvey, I. 2000. Investigations into the biochemical basis for nematode resistance in roots of three musa cultivars in response to radopholus s imilis infection. Journal of Agricultural and Food Chemistry, 48(11): 5297-5301.
Dal Cortivo, C., Barion, G., Ferrari, M., Visioli, G., Dramis, L., Panozzo, A. and Vamerali, T., 2018. Effects of field inoculation with vam and bacteria consortia on root growth and nutrients uptake in common wheat. Sustainability, 10(9): 3286.

Dei, H. K. 2011. Soybean as a feed ingredient for livestock and poultry. In Recent trends for enhancing the diversity and quality of soybean products. IntechOpen.

Feucht, W., Treutter, D. and Christ, E., 1997. Role of flavanols in yellowing beech trees of the Black Forest. Tree physiology, 17(5): 335-340.

Fujikake, H., Yamazaki, A., Ohtake, N., Sueyoshi, K., Matsuhashi, S., Ito, T., Mizuniwa, C., Kume, T., Hashimoto, S., Ishioka, N. S. and Watanabe, S. 2003. Quick and reversible inhibition of soybean root nodule growth by nitrate involves a decrease in sucrose supply to nodules. Journal of Experimental Botany, 54(386): 13791388. DOI: $10.1093 / \mathrm{jxb} / \mathrm{erg} 147$

Glombitza, K. W. and Gerstberger, G. 1985. Phlorotannins with dibenzodioxin structural elements from the brown alga Eisenia arborea. Phytochemistry, 24(3): 543-551.

Harborne, J. B. 1980. Plant phenolics, Encyclopedia of Plant Physiology, Secondary, Plant Products, 8: 329-402.

He, Z., He, C., Zhang, Z., Zou, Z. and Wang, H. 2007. Changes of antioxidative enzymes and cell membrane osmosis in tomato colonized by arbuscular mycorrhizae under $\mathrm{NaCl}$ stress. Colloids and Surfaces B: Biointerfaces, 59(2): 128133.

Jean-Blain, C. 1998. Aspects nutritionnels et toxicologiques des tanins. Revue de Médecine vétérinaire, 149(10): 911920 .

Jeaun, J. M., Annie F. and Chrystian J. L. 2005. Les composés phénoliques des végétaux,: 203- 204.

King, A. M. Y. and Young, G. 1999. Characteristics and occurrence of phenolic phytochemicals. Journal of the American Dietetic Association, 99(2): 213-218.

Lancashire, P. D., Bleiholder, H., Boom, T. V. D., Langelüddeke, P., Stauss, R., Weber, E. and Witzenberger, A. 1991. A uniform decimal code for growth stages of crops and weeds. Annals of applied Biology, 119(3): 561601.

Maillard, M. N. 1996. Contribution à l'amélioration de la stabilité organoleptique de la bière: suivi du comportement de quelques antioxydants endogènes de l'orge et du malt(Doctoral dissertation, École nationale supérieure des industries agricoles et alimentaires (Massy, Essonne).

Makkar, H. P., Siddhuraju, P. and Becker, K. 2007. Plant secondary metabolites. Humana Press. 
Mapope, N. and Dakora, F. D. 2016. N2 fixation, carbon accumulation, and plant water relations in soybean (Glycine max L. Merrill) varieties sampled from farmers' fields in South Africa, measured using $15 \mathrm{~N}$ and $13 \mathrm{C}$ natural abundance. Agriculture, Ecosystems and Environment, 221: 174-186.

Marschner H. 1995. Mineral Nutrition of Higher Plant, $2^{\text {nd }}$ (ed), Academic Press Limeted, Text Book.

Mateos-Aparicio, I., Redondo Cuenca, A., Villanueva-Suárez, M. J. and Zapata-Revilla, M. A. 2008. Soja, una prometedora fuente de salud. Nutrición Hospitalaria, 23(4): 305-312.

Mithöfer, A., Wanner, G. and Boland, W. 2005. Effects of feeding Spodoptera littoralis on lima bean leaves. II. Continuous mechanical wounding resembling insect feeding is sufficient to elicit herbivory-related volatile emission. Plant Physiology, 137(3): 1160-1168.

Mueller-Harvey, I. and Mc Allan, A. B. 1992. Tannins: their biochemistry and nutritional properties. Advanced. Plant Cell Biochem. Biotechnol. (1): 151-217.

Naamala, J., Jaiswal, S. K. and Dakora, F. D. 2016. Microsymbiont diversity and phylogeny of native bradyrhizobia associated with soybean (Glycine max L. Merr.) nodulation in South African soils. Systematic and applied microbiology, 39(5): 336-344.

Naher U. A., Radziah O., Shamsuddin Z. H., Halimi M. S. and Mohd Razi I. 2009. Growth Enhancement and Root Colonization of Rice Seedlings by Rhizobium and Corynebacterium spp. International Journal of Agricultural and Biology, 11: 586-590.

Nicholson, R. L. and Hammerschmidt, R. 1992. Phenolic compounds and their role in disease resistance. Annual Review of Phytopathology, 30: 369-89.

Panhwar, Q. A., Radziah, O., Sariah, M. and Ismail, M. R. 2009. Solubilization of different phosphate forms by phosphate solubilizing bacteria isolated from aerobic rice. Int J Agric Biol, 11(6): 667-673.
Qrbanly, M., Hashemyfar, S. and Fallah, A. 2006. The interaction of irrigation and nitrogen on some morphological and physiological traits of rice plants (Oryza sativa L.). Journal of Agricultural Science, 12(2): 415428.

Riaz, M. N. 2006. Soy Applications in Food. Boca Raton, FL: CRC Press. ISBN 0-8493-2981-7.

Soka, G. and Ritchie, M. 2014. Arbuscular mycorrhizal symbiosis, ecosystem processes and environmental changes in tropical soils. Applied ecology and environmental research 13(1): 229-245.

Song, F., Song, G., Dong, A. and Kong, X. 2011. Regulatory mechanisms of host plant defense responses to arbuscular mycorrhiza. Acta Ecologica Sinica, 31(6): 322-327.

Tylka G. L., Hussey, R. S. and Roncadori R. W. 1991 Interactions of Vesicular-Arbuscular Mycorrhizal Fungi, Phosphorus, and Heterodera glycines on Soybean. Journal of Nematology, 23(I), 122-133.

Van Der Heijden, M. G., Bardgett, R. D. and Van Straalen, N. M. 2008. The unseen majority: soil microbes as drivers of plant diversity and productivity in terrestrial ecosystems. Ecology letters, 11(3): 296-310.

War, A. R., Paulraj, M. G., Ahmad, T., Buhroo, A. A., Hussain, B., Ignacimuthu, S. and Sharma, H. C. 2012. Mechanisms of plant defense against insect herbivores. Plant signaling and behavior, 7(10): 13061320 .

Wink, M. 2003. Evolution of secondary metabolites from an ecological and molecular phylogenetic perspective. Phytochemistry, 64: 3-19.

Woodward, A. and Coppock, D. L. 1995. Role of plant defense in the utilization of native browse in southern Ethiopia. Agroforestry Systems, 32 (2): 147-161.

Wu, O. S. and Xia, R. X. 2006. Arbuscular mycorrhizal fungi influence growth, osmotic adjustment and photosynthesis of citrus under well-watered and water stress conditions. Journal of Plant Physiology, 163: 417-425. 